\title{
PENGELOLAAN HUTAN RAKYAT OLEH KELOMPOK PEMILIK HUTAN RAKYAT DI DESA BANDAR DALAM KECAMATAN SIDOMULYO KABUPATEN LAMPUNG SELATAN
}

\section{(PRIVATE FOREST MANAGEMENT \\ BY PRIVATE FOREST OWNERS GROUP IN BANDAR DALAM VILLAGE SIDOMULYO DISTRICT SOUTH LAMPUNG REGENCY)}

\author{
Abdian Roby Pratama ${ }^{1)}$, Slamet Budi Yuwono ${ }^{2)}$, dan Rudi Hilmanto ${ }^{2)}$ \\ ${ }^{1)}$ Mahasiswa Jurusan Kehutanan Fakultas Pertanian Universitas Lampung, \\ ${ }^{2)}$ Staf Pengajar Jurusan Kehutanan Fakultas Pertanian Universitas Lampung, \\ Jurusan Kehutanan Fakultas Pertanian Universitas Lampung \\ J1. Soemantri Brojonegoro No. 1 Bandar Lampung, 35145 \\ E-mail : anrotama@yahoo.co.id
}

\begin{abstract}
ABSTRAK
Hutan rakyat merupakan salah satu alternatif pemecahan masalah terhadap tekanan sumber daya hutan. Manfaat yang bisa diperoleh dari pengelolaan hutan rakyat antara lain pemenuhan kebutuhan kayu, peningkatan pendapatan masyarakat, dan peningkatan produktivitas lahan milik masyarakat. Manfaat yang diperoleh masyarakat tergantung pada pengelolaan yang dilakukan oleh pemilik hutan rakyat. Tujuan penelitian ini adalah untuk mengetahui karakteristik sosial dan ekonomi masyarakat yang turut berpartisipasi dalam mengelola hutan rakyat, dan untuk mengetahui tingkat pengelolaan hutan rakyat meliputi aspek perencanaan, organisasi, pelaksanaan, evaluasi dan monitoring. Penelitian dilaksanakan pada bulan agustus sampai dengan bulan september 2014 di Desa Bandar Dalam Kecamatan Sidomulyo Kabupaten Lampung Selatan. Jumlah sampel dalam penelitian ini ada 38 orang responden yang diperoleh dengan menggunakan metode simple random sampling. Metode analisis data yang digunakan dalam penelitian ini yaitu analisis deskriptif kualitatif. Berdasarkan hasil penelitian, dapat disimpulkan bahwa: (1) karakteristik sosial dan ekonomi masyarakat yang mengelola hutan rakyat sebagian besar termasuk dalam usia produktif kerja dan mempunyai pekerjaan sampingan, jumlah tanggungan keluarga hanya sedikit dan luas lahan hutan rakyat yang mereka kelola cukup luas sehingga pendapatan mereka cukup tinggi, meskipun sebagian besar tingkat pendidikannya rendah; dan (2) pengelolaan hutan rakyat yang dilakukan terdiri dari aspek perencanaan yang termasuk dalam kategori sedang, aspek organisasi termasuk dalam kategori sedang, aspek pelaksanaan penanaman termasuk dalam kategori baik, aspek pelaksanaan pemeliharaan termasuk dalam kategori sedang, aspek pelaksanaan pemanenan termasuk dalam kategori baik, aspek pelaksanaan pemasaran dalam kategori buruk, dan aspek monitoring dan evaluasi termasuk dalam kategori sedang. Secara keseluruhan tingkat pengelolaan hutan rakyat termasuk kategori sedang.
\end{abstract}

Kata kunci: Hutan rakyat, pengelolaan hutan, pemilik hutan rakyat

\section{ABSTRACT}

The private forest is one of the alternative solutions to the pressure of forest resources. The benefits to be gained from private forests management includes fulfill the needs of wood, increase public revenues, and increase the productivity of land. The benefit has received by the public depends on the management carried out by private forest owners. The purposes of this study were to determine the social and economic characteristics of people who 
participate in managing private forests, and to determine the level of private forest management covers all aspects of planning, organizing, actuating, evaluation and monitoring. The research was conducted on August till September 2014 in Bandar Dalam village Sidomulyo District of South Lampung. The numbers of samples were 38 respondents by simple random sampling method. Data analysis methods used qualitative descriptive analysis. The results, were it can be concluded that: (1) the social and economic characteristics of the people who manage private forests mostly included in the productive age work and have a second job, amount of family burden is only a bit, and private forests land that they manage quite extensive so that their income quite high, although most low level of education; and (2) private forest management consisted of the planning aspect in medium category, organizational aspect in medium category, planting implementation aspect in both category, implementation of maintenance aspect in medium category, harvesting implementation aspect in both category, marketing implementation aspect in poor category, and monitoringevaluation aspect are in medium category. Overall level of private forest management is medium category.

Key words: Private forest, forest management, private forest owners

\section{PENDAHULUAN}

Luas kawasan hutan di Indonesia saat ini telah mengalami penurunan yang cukup besar. Hal ini antara lain disebabkan semakin bertambahnya jumlah penduduk sehingga untuk memenuhi kebutuhan hidup masyarakat mulai merambah ke kawasan hutan. Salah satu alternatif pemecahan masalah terhadap tekanan sumber daya hutan adalah dengan pembangunan hutan rakyat (Alviya dkk, 2007). Menurut Departemen Kehutanan (1999), hutan rakyat adalah hutan yang tumbuh di atas tanah yang telah dibebani hak milik artinya hutan tersebut tidak pada tanah negara. Hutan rakyat di Desa Bandar Dalam Kecamatan Sidomulyo Kabupaten Lampung Selatan telah lama menjadi bagian dari kehidupan masyarakat. Hutan rakyat tersebut memiliki pola tanam campuran dengan sistem agroforestry dan ada juga pola tanam monokultur di sebagian lahan masyarakat. Pengelolaan hutan rakyat pada umumnya dilakukan secara sederhana dan tradisional oleh masyarakat setempat, biasanya ditanami tumbuhan berkayu dan juga tanaman pangan (Sudiana, dkk, 2009).

Pelaksanaan dalam pengelolaan hutan rakyat diperlukan perencanaan yang tepat agar kelestarian hutan rakyat tetap terjaga, selain itu organisasi berperan penting sebagai pengambil keputusan setelah rencana pada pengelolaan hutan sudah dirancang dengan baik. Pemerintah daerah juga perlu melakukan penyuluhan dan monitoring kepada masyarakat sehingga dalam pengelolaan hutan rakyat dapat menerapkan teknik-teknik atau sistem pengelolaan yang baik. Bertolak dari hal tersebut maka perlu dilakukan penelitian mengenai bagaimana pengelolaan yang dilakukan di sana mulai dari perencanaan, organisasi, pelaksanaan, dan evaluasi monitoringnya sehingga dapat diketahui tingkat pengelolaan hutan rakyat di daerah tersebut.

Tujuan Penelitian ini adalah: (1) Untuk mengetahui karakteristik sosial dan ekonomi masyarakat Desa Bandar Dalam Kecamatan Sidomulyo Kabupaten Lampung Selatan yang turut berpartisipasi dalam mengelola hutan rakyat; (2) Untuk mengetahui tingkat pengelolaan hutan rakyat di Desa Bandar Dalam Kecamatan Sidomulyo Kabupaten Lampung Selatan meliputi aspek perencanaan, organisasi, pelaksanaan, evaluasi dan monitoring. 


\section{METODOLOGI PENELITIAN}

Penelitian ini dilaksanakan di Desa Bandar Dalam Kecamatan Sidomulyo Kabupaten Lampung Selatan. Waktu penelitian yaitu pada bulan Agustus sampai September 2014. Alat yang digunakan dalam penelitian ini antara lain: alat tulis, kalkulator, komputer, daftar pertanyaan berupa kuisioner, kamera digital, alat perekam suara (recorder), dan alat penunjang lainnya. Sedangkan yang menjadi objek penelitian adalah anggota kelompok pemilik hutan rakyat.

Data yang dipergunakan dalam penelitian ini meliputi data primer dan data sekunder. Data primer merupakan data yang diperoleh langsung dari responden melalui wawancara secara langsung dengan menggunakan daftar pertanyaan (kuisioner yang telah disusun), sedangkan data sekunder diperoleh melalui studi pustaka/literatur yaitu dengan cara membaca dan mengutip teori-teori yang relevan dari berbagai sumber, serta data-data yang didapat dari lembaga-lembaga/instansi-instansi yang terkait dengan penelitian ini.

Metode pengumpulan sampel dilakukan dengan menggunakan metode simple random sampling. Desa Bandar Dalam memiliki kelompok pemilik hutan rakyat yang beranggotakan sebanyak 308 orang. Berdasarkan formula Slovin (Arikunto, 2011), maka didapatkan jumlah responden sebanyak 38 orang responden.

Data dan informasi yang diperoleh, diolah dengan sistem tabulasi guna mengetahui tingkat pengelolaan hutan rakyat yang dilakukan kelompok pemilik hutan rakyat dari setiap aspek yaitu perencanaan, pelaksanaan, organisasi, evaluasi dan monitoring. Tabulasi ini bertujuan untuk mengetahui bobot nilai pada masing-masing pertanyaan. Berdasarkan Fauziyah (2009), penentuan skor dari pertanyaan pada kuesioner digunakan bobot yang diberikan sebagai berikut:

a. Untuk jawaban yang sesuai dengan harapan akan diberi skor 100

b. Untuk jawaban yang kurang sesuai dengan harapan akan diberi skor 50

c. Untuk jawaban yang tidak sesuai harapan akan diberi skor 0

Untuk mendapatkan tingkat pengelolaan data yang berasal dari data kuesioner dilakukan pengkategorian dengan menggunakan rumus sebagai berikut :

$$
I=\frac{N T-N R}{K}
$$

Keterangan :

I = Interval

NT $=$ Total nilai tertinggi

$\mathrm{NR} \quad=$ Total nilai terendah

$\mathrm{K} \quad$ = Kategori jawaban (Yitnosumarto, 2006).

Analisis data yang digunakan dalam penelitian ini menggunakan metode analisis deskriptif. Menurut Sugiyono (2008), analisis deskriptif merupakan metode penelitian dengan cara mengumpulkan data-data sesuai dengan yang sebenarnya kemudian data-data tersebut disusun, diolah dan dianalisis untuk dapat memberikan gambaran mengenai masalah yang ada.

\section{HASIL DAN PEMBAHASAN}

\section{A. Karakteristik Sosial dan Ekonomi Masyarakat Desa Bandar Dalam yang Turut Berpartisipasi dalam Pengelolaan Hutan Rakyat}

\section{Umur Responden}

Masyarakat Desa Bandar Dalam yang mengelola hutan rakyat memiliki umur berkisar antara 33 - 80 tahun dari kisaran tersebut ada 34 responden $(89,47 \%)$ yang masih termasuk 
dalam usia produktif kerja dan 4 responden (10,53\%) tidak termasuk dalam usia produktif kerja. Hal ini menunjukkan bahwa sebagian besar responden yang mengelola hutan rakyat merupakan pemilik hutan rakyat yang masih produktif untuk bekerja. Usia produktif kerja menurut Badan Pusat Satistik (2014) yaitu umur 15-64 tahun.

\section{Tingkat Pendidikan}

Sebagian besar responden berpendidikan dasar (Sekolah Dasar dan Sekolah Menengah Pertama) yaitu sebanyak 30 responden (79\%), berpendidikan menengah (Sekolah Menengah Atas) sebanyak 6 responden $(15,8 \%)$, berpendidikan tinggi (Perguruan Tinggi) hanya 1 orang responden (2,6\% responden), dan tidak sekolah ada 1 responden $(2,6 \%)$. Hal ini menandakan bahwa sebagian besar tingkat pendidikan pemilik hutan rakyat tergolong rendah. Tingkat pendidikan akan mempengaruhi proses penyerapan informasi, penerapan pengetahuan, sikap dan prilaku responden dalam mengelola hutan rakyat. Ada beberapa faktor penyebab rendahnya pendidikan masyarakat yaitu kemampuan ekonomi masyarakat yang kurang, kurangnya kesadaran masyarakat akan pentingnya pendidikan, dan terbatasnya fasilitas pendidikan (Suryaningsih, 2012).

\section{Jumlah Tanggungan Keluarga Responden}

Jumlah tanggungan keluarga responden dari ke-38 responden ada 21 responden $(55,3 \%)$ yang memiliki jumlah tanggungan keluarga berkisar antara 1-4 orang, 16 responden $(42,1 \%)$ memiliki jumlah tanggungan keluarga berkisar antara 5-8 orang, dan 1 reponden $(2,6 \%)$ memiliki jumlah tanggungan keluarga berkisar antara 9-12 orang. Hal ini berarti sebagian besar responden memiliki tanggungan keluarga yang sedikit dan sudah memenuhi jumlah ideal rata-rata anggota keluarga menurut BKKBN (1994) yaitu empat orang, namun masyarakat juga perlu memperhatikan program Keluarga Berencana (KB) karena semakin sedikit jumlah tanggungan keluarga maka beban yang di tanggung reponden juga akan semakin ringan.

\section{Pekerjaan Responden}

Berdasarkan hasil data yang diperoleh, dari total 38 reponden (100\%) seluruhnya memiliki pekerjaan pokok sebagai pemilik hutan rakyat dan diantaranya ada yang memiliki pekerjaan sampingan yaitu sebanyak 18 responden $(47,4 \%)$ (sebagai wirausaha, pegawai desa, peternak, wiraswasta, pedagang, supir, dan buruh), dan sisanya 20 responden $(52,6 \%)$ adalah pemilik hutan rakyat murni. Menurut Basir (1999), pekerjaan pokok adalah pekerjaan yang dilakukan seseorang dengan curahan jam kerja terbanyak dan atau pekerjaan tersebut memberikan sumbangan pendapatan yang terbesar, sedangkan pekerjaan sampingan merupakan pekerjaan tambahan yang dimiliki seseorang, biasanya pekerjaan ini ada dikarenakan pendapatan yang diperoleh dari pekerjaan pokok belum mencukupi untuk memenuhi kebutuhan pokok sehari-hari atau pekerjaan sampingan ada karena masih ada sisa waktu seseorang setelah mengerjakan pekerjaan pokoknya.

\section{Luas Lahan yang Dikelola}

Sebagian besar responden $(55,26 \%)$ memiliki luas lahan $\geq 2$ ha dan sebagian lagi $(44,74 \%)$ memiliki luas lahan $<2$ ha. Luas lahan yang dikelola berpengaruh terhadap besarnya pendapatan yang diterima pemilik hutan rakyat, semakin luas lahan maka semakin besar pendapatan yang diterima sehingga mampu memenuhi kebutuhan hidup keluarganya (Saihani, 2011).

Hal ini berarti sebagian besar responden mempunyai kesadaran dan tanggung jawab dalam memenuhi kebutuhan hidup keluarganya. 


\section{Pendapatan Responden}

Sebagian besar responden memiliki pendapatan antara Rp. 1.000.000,00 Rp. 2.000.000,00/bulan. Pendapatan merupakan penerimaan dari hasil suatu usaha yang telah dikurangi dengan biaya-biaya selama proses produksi. Pendapatan ini diperoleh dari hasil tanaman kehutanan dan pertanian. Beragamnya mata pencaharian responden berpengaruhi secara langsung dengan besarnya pendapatan responden. Responden yang memiliki pekerjaan sampingan akan memiliki pendapatan yang lebih besar dibandingkan dengan responden yang tidak mempunyai pekerjaan lain.

Berdasarkan Sajogyo (1977), metode perkiraan garis kemiskinan dengan membandingkan besarnya kebutuhan minimum dalam beras-ekuivalen. Menurut Sajogyo, kebutuhan minimum rakyat Indonesia adalah sebesar $360 \mathrm{~kg}$ dan $240 \mathrm{~kg}$ beras-ekuivalen per orang per tahun masing-masing untuk daerah kota dan daerah perdesaan.

Bandar Dalam termasuk daerah perdesaan, dari pendapat Sajogyo (1977) kebutuhan minimum beras daerah perdesaan sebesar $240 \mathrm{~kg}$ per orang per tahun dengan memperhatikan harga beras yang berlaku di Desa Bandar Dalam tahun 2014 yaitu Rp7.500,00/kg, diperoleh garis kemiskinan sebesar Rp1.800.000,00/jiwa/tahun maka per bulan sebesar Rp150.000,00/bulan per orang. Dengan demikian, dapat dikatakan rata-rata pendapatan rumah tangga per kapita pemilik hutan rakyat sudah diatas garis kemiskinan, artinya pemilik hutan rakyat di Desa Bandar Dalam tidak tergolong penduduk miskin.

\section{B. Pengelolaan Hutan Rakyat}

\section{Perencanaan}

Berdasarkan hasil data yang diperoleh, sebagian besar responden 81,6\% (31 responden) termasuk kategori sedang dan hanya $18,4 \%$ (7 responden) termasuk dalam kategori baik. Hal ini menunjukkan bahwa sebagian besar pemilik hutan rakyat sudah mengetahui namun belum memahami dengan baik tentang perencanaan dan pentingnya perencanaan. Pemilik hutan rakyat di Desa Bandar Dalam tidak melakukan perencanaan secara khusus dalam mengelola lahan milik mereka. Perencanaan yang mereka lakukan tidak dilaksanakan secara tertulis karena kegiatan perencanaan dilakukan oleh masing-masing pemilik sehingga pemilik hutan rakyat hanya membuat perencanaan berdasarkan informasi kondisi iklim, kondisi tanah, siklus air yang mereka ketahui, serta jumlah dana yang mereka miliki.

Pemilik hutan rakyat yang merencanakan pengelolaannya dengan baik rata-rata mempersiapkan modalnya berkisar antara Rp.4.000.000,- sampai dengan Rp.10.000.000,-. Modal ini digunakan untuk biaya produksi yaitu berupa pembelian alat (arit, cangkul, hand sprayer), pembelian pupuk (urea, kompos, NPK, TSP), pembelian bibit, pembelian bahan pengendalian hama dan penyakit, dan tenaga kerja.

Sebagian besar pemilik hutan rakyat berencana untuk menanam tanaman sengon (Albazia falcataria) di lahan milik mereka alasannya karena tanaman tersebut cepat panen dan batangnya memiliki nilai jual yang cukup tinggi. Hal ini sesuai dengan yang dikatakan oleh Hardiatmi (2010) bahwa sengon merupakan pohon yang pertumbuhannya tercepat di dunia. Pada umur 1 tahun dapat mencapai tinggi $7 \mathrm{~m}$ dan pada umur 12 tahun dapat mencapai tinggi $39 \mathrm{~m}$, dengan diameter $60 \mathrm{~cm}$ dan tinggi cabang 10-30 m. Selain itu harga kayunya dapat mencapai Rp. $650.000 / \mathrm{m}^{3}$ atau lebih dan bahkan sejumlah analisis menyebutkan bahwa harga kayu sengon diprediksi akan terus meningkat secara rasional sekitar 4-5 tahun kedepan menjadi Rp. 1 Juta per m3. Hal ini berdasarkan pada permintaan pasar internasional dan domestik terhadap sengon yang terus meningkat karena sengon dikenal sebagai kayu budidaya yang dapat mengurangi tekanan terhadap hutan alam. 


\section{Organisasi}

Berdasarkan hasil data yang diperoleh, sebagian besar responden 94,7\% (36 responden) termasuk kategori sedang, hanya 5,3\% (2 responden) yang termasuk kategori buruk, dan tidak ada responden yang termasuk dalam kategori baik. Hal ini menunjukkan bahwa sebagian besar pemilik hutan rakyat belum memahami pentingnya organisasi untuk mencapai tujuan bersama. Menurut Widiyanti (2009) pada umumnya kelompok pemilik hutan rakyat memiliki tujuan yang sama yaitu meningkatkan kesejahteraan anggota dan masyarakat sekitar dengan meningkatkan penghasilan pemilik hutan rakyat dan kualitas produksi. Adanya kesamaan tujuan antar anggotanya semakin mendukung kinerja dan produktivitas para anggota untuk berkontribusi dalam kelompok.

Kelompok pemilik hutan rakyat di Desa Bandar Dalam sering mengadakan pertemuan setiap 3 bulan sekali. Adapun yang dibahas dalam pertemuan tersebut yaitu mengenai kehutanan, perkebunan, dan pertanian pangan. Kehadiran responden pada pertemuan tersebut cukup rendah, ini dikarenakan masing-masing responden memiliki kesibukannya masingmasing. Kelompok pemilik hutan rakyat di Desa Bandar Dalam tidak memiliki aturan-aturan khusus yang berlaku, akan tetapi di kelompok ini sering mengadakan simpanan wajib yaitu sebesar 10 ribu rupiah tiap bulannya.

Proses pengambilan keputusan yang dilakukan oleh kelompok pemilik hutan rakyat sangat menjunjung tinggi musyawarah antar sesama anggotanya. Keterlibatan anggota dalam pengambilan keputusan cukup tinggi, ini artinya seluruh anggota dalam kelompok memiliki kesempatan yang sama untuk memutuskan sesuatu yang berkaitan dengan kelangsungan kinerja kelompoknya.

Kelompok pemilik hutan rakyat di Desa Bandar Dalam sayangnya belum pernah mengadakan seminar/pelatihan-pelatihan yang berkaitan dengan pengelolaan hutan rakyat. Ini disebabkan karena kurangnya tenaga ahli dalam hal pengelolaan hutan rakyat. Penyuluhan dari Dinas Kehutanan pun jarang sekali dilakukan dalam satu tahun hanya dilakukan satu kali. Bantuan yang pernah diberikan oleh Dinas Kehutanan pada kelompok pemilik hutan rakyat di Desa Bandar Dalam yaitu Program Kebun Bibit Rakyat (KBR) yang merupakan salah satu program Rehabilitasi Hutan dan Lahan (RHL) yang berbasis swakelola kelompok masyarakat dan bertujuan untuk menyediakan bibit berkualitas baik sehingga diharapkan dapat meningkatkan minat tanam masyarakat. Lembaga Non Dinas seperti LSM (Lembaga Swadaya Masyarakat) pun belum pernah memberikan pelatihan/penyuluhan kepada masyarakat di Desa Bandar Dalam khususnya pada kelompok pemilik hutan rakyat. Menurut Mahbub (2007), padahal peran penyuluh dalam hal ini adalah untuk memperkuat kemampuan-kemampuan dan potensi para pemilik hutan rakyat untuk memperbaiki usaha mereka dalam mengelola dan memanfaatkan hutan.

\section{Pelaksanaan}

\section{a. Pelaksanaan Kegiatan Penanaman}

Berdasarkan hasil data yang diperoleh, sebanyak 21 responden $(55,3 \%)$ dalam kategori baik dan 17 responden $(44,7 \%)$ dalam kategori sedang. Hal ini berarti sebagian besar pemilik hutan rakyat telah memahami dan melaksanakan penanaman dengan baik. Kegiatan penanaman ini terdiri dari kegiatan penyediaan bibit, persiapan lahan, dan penanaman. Jenis tanaman yang dikembangkan oleh masyarakat di lahan yang mereka kelola yaitu jenis tanaman kehutanan, tanaman MPTS, tanaman perkebunan dan tanaman pertanian. Tanaman kehutanan yang ditanam adalah jati (Tectona grandis), sengon (Albazia falcataria), mahoni (Swetenia mahagoni), waru (Hibiscus tiliaceus), bayur (Pterospermum javanicum), akasia mangium (Acacia mangium), medang (Cinnamomum spp), jabon (Anthocephalus cadamba) dan cempaka (Michelia champaca). Tanaman MPTS yang ditanam adalah petai (Parkia speciosa), kakao (Theobroma cacao), kopi (Coffea spp.), melinjo (Gnetum gnemon), jengkol 
(Pithecelobium labatum), durian (Durio zibethinus), duku (Lansium domesticum), manggis (Garcinia mangostana), cengkeh (Syzygium aromaticum), dan rambutan (Nephelium lappaceum). Tanaman perkebunan yang ditanam adalah kelapa (Cocos nucifera), kelapa sawit (Elaeis guineensis), dan pisang (Musa spp.). Sedangkan tanaman pertanian yang ditanam adalah jagung (Zea mays) dan padi gogo (Oryza sativa). Akan tetapi di lahan hutan rakyat di Desa Bandar Dalam sebagian besar tanaman kehutanannya adalah sengon dan jati.

Pengadaan bibit tanaman yang dilakukan pemilik hutan rakyat ada yang diusahakan sendiri dan ada pula yang diperoleh dari bantuan pemerintah. Pada pengadaan bibit yang diusahakan sendiri atau secara swadaya didapatkan dari membeli di pembibitan, sedangkan bibit bantuan pemerintah didapatkan dari Dinas Kehutanan melalui program KBR (Kebun Bibit Rakyat).

Penyiapan lahan diperlukan agar lahan menjadi tempat tumbuh yang baik bagi tanaman (Setiawan, 1996). Penyiapan lahan dilakukan pemilik hutan rakyat dengan membersihkan lokasi tanam dari tumbuhan seperti alang-alang, gulma, dan semak belukar. Penyiangan biasanya dilakukan satu bulan sebelum tanam dan pada musim kemarau. Selain itu, pemilik hutan rayat juga membuat lubang tanam, memberi pupuk, dan memasang ajir pada lahannya Pemilik hutan rakyat juga memperhatikan jarak tanam, jarak tanam yang digunakan pemilik hutan rakyat biasanya $3 \times 3$ meter. Pemilik hutan rayat yang memiliki lahan di tanah yang miring melakukan penanaman dengan mengikuti kontur/ lereng, hal ini dilakukan agar tanaman dapat menahan erosi dan banjir. Selain itu, pemilik hutan rayat juga melakukan rotasi tanaman dengan tujuan untuk memperbaiki struktur tanah dan menghambat penyebaran hama dan penyakit.

\section{b. Pelaksanaan Kegiatan Pemeliharaan}

Berdasarkan hasil data yang diperoleh, sebanyak 12 responden (31,6\%) telah melaksanakan kegiatan pemeliharaan dengan baik dan 26 responden $(68,4 \%)$ dalam kategori sedang. Sedikitnya responden yang dalam kategori baik dibandingkan dengan responden yang kategori sedang disebabkan karena pemilik hutan rakyat menganggap tanah/lahan mereka sangat subur sehingga tidak perlu melakukan pemeliharaan yang intensif.

Kegiatan pemeliharaan merupakan kegiatan yang dilakukan masyarakat pengelola hutan rakyat untuk memelihara tanaman miliknya sehingga tanaman tersebut dapat tumbuh dengan baik dan memberikan hasil yang maksimal (Simon, 2004). Kegiatan ini terdiri dari kegiatan penyiangan, pemupukan, pemangkasan cabang, penjarangan, pemberantasan hama dan penyakit.

Penyiangan adalah mengendalikan tanaman pengganggu seperti gulma dan alang-alang dengan cara menghilangkan atau memotongnya (Mulyana dan Asmarahman, 2010). Sebagian besar pemilik hutan rakyat sering melakukan kegiatan penyiangan ini, dari 38 responden ada 21 responden $(55,3 \%)$ yang selalu melakukannya dan hanya 17 responden $(44,7 \%)$ yang hanya kadang-kadang saja melakukannya. Ini berarti, sebagian besar pemilik hutan rakyat sudah mengetahui bahwa gulma mengganggu pertumbuhan tanaman karena menjadi pesaing tanaman untuk memperoleh cahaya, air dan unsur hara dalam tanah.

Pemeliharaan yang berikutnya yaitu pemupukan. Tujuan dari pemupukan adalah menjaga ketersediaan unsur hara agar selalu tersedia di dalam tanah (Mulyana dan Asmarahman, 2010). Pemupukan yang dilakukan pemilik hutan rakyat dari 38 responden, ada 20 responden $(52,6 \%)$ yang selalu melakukan pemupukan, 14 responden $(36,9 \%)$ kadang-kadang saja melakukannya dan hanya 4 responden $(10,5 \%)$ yang tidak pernah melakukan pemupukan. Ini berarti sebagian besar responden sudah memahami pentingnya pemupukan untuk memenuhi kebutuhan hara tanaman yang tidak diperoleh dari tanah.

Pemangkasan cabang dilakukan agar tinggi pohon bebas cabang tetap tinggi, memudahkan pemanenan, dan berguna untuk mengurangi serangan hama dan penyakit. 
Selain itu penjarangan juga diperlukan agar memberikan ruang tumbuh yang optimal dan menebang pohon yang telah rusak (Mulyana dan Asmarahman, 2010). Hampir seluruh pemilik hutan rakyat/responden tidak melakukan pemangkasan cabang dan penjarangan, ini dikarenakan hampir seluruh responden belum mengetahui pentingnya pemangkasan cabang dan penjarangan. Selain itu, pada saat penanaman jarak tanam sudah diatur sehingga mereka pikir tidak perlu lagi dilakukan penjarangan.

Hanya sedikit pemilik hutan rakyat yang sering melakukan pemberantasan hama dan penyakit pada tanaman kehutanannya, dari 38 responden hanya 8 responden $(21,1 \%)$ yang selalu melakukannya, 20 responden $(52,6 \%)$ kadang-kadang saja melakukannya, dan 10 responden $(26,3 \%)$ tidak pernah melakukannya. Ini disebabkan karena kurangnya pengetahuan masyarakat tentang hama dan penyakit tanaman khususnya tanaman kehutanan serta bagaimana cara pemberantasannya sehingga, banyak pemilik hutan rakyat yang hanya membiarkannya saja tanpa ada usaha pengendalian apapun. Salah satu pengendalian yang dilakukan pemilik hutan rakyat yaitu dengan menggunakan zat kimia (pestisida) seperti menggunakan insektisida, fungisida, herbisida, bakterisida dan lain sebagainya. Biasanya juga pestisida yang dipakai pemilik hutan rakyat pada tanaman kehutanan sama dengan pestisida yang digunakan pada tanaman pertanian. Namun, pada penggunaannya pemilik hutan rakyat tetap melihat apakah hama yang menyerang tanaman kehutanan sama dengan hama yang menyerang tanaman pertanian miliknya atau tidak.

Hasil wawancara yang diadapat dari kuisioner hampir semua responden mengatakan bahwa kegiatan pemeliharaan berpengaruh terhadap peningkatan kualitas tumbuhan. Ini artinya mereka sadar bahwa pemeliharaan cukup penting dalam pembudidayaan tanaman dan mereka pun telah merasakan sendiri dampak dari kegiatan pemeliharaan yang telah mereka lakukan terhadap kualitas pertumbuhan tanaman.

\section{c. Pelaksanaan Kegiatan Pemanenan}

Berdasarkan hasil data yang diperoleh, responden yang termasuk dalam kategori baik ada sebanyak 20 responden $(52,6 \%)$ dan 18 responden $(47,4 \%)$ termasuk dalam kategori sedang. Hal ini berarti sebagian besar responden/pemilik hutan rakyat telah mengetahui dan menjalankan pemanenan dengan baik yaitu sesuai dengan prosedur pemanenan dimana tanaman yang dipanen harus sudah siap panen.

Kegiatan pemanenan merupakan kegiatan yang pemilik hutan rakyat lakukan untuk mengambil hasil dari tanaman baik berupa kayu, daun, akar, buah, dan sebagainya yang bersumber dari tanaman. Pemanenan kayu yang dilakukan pemilik hutan rakyat dari 38 responden ada 8 responden $(21,1 \%)$ yang memanennya sesuai dengan umur panen pohon seperti: sengon (6-7 tahun), jati (30 tahun), mahoni (15 tahun), 2 responden (5,3\%) memanen berdasarkan diameter batang kayunya yaitu lebih dari $30 \mathrm{~cm}$, dan 28 responden $(73,6 \%)$ memanen kayunya sesuai kebutuhan pemilik hutan rakyat yaitu untuk kebutuhan mendadak seperti: biaya anak sekolah, biaya berobat, dan sebagainya. Menurut Pramono dkk (2010), pemanenan kayu adalah pemanfaatan yang rasional dan penyiapan suatu bahan baku dari alam menjadi sesuatu yang siap dipasarkan untuk bermacam-macam kebutuhan manusia. Hasil kayu tersebut selain dipasarkan/dijual, ada juga yang dipakai sendiri yaitu untuk membangun/ merenovasi rumah, membangun kandang, dan kayu bakar.

Hutan rakyat di Desa Bandar Dalam selain memiliki hasil hutan kayu juga memiliki hasil hutan bukan kayu. Pemanenan hasil hutan bukan kayu yang dilakukan pemilik hutan rakyat dari 38 responden, ada 35 responden $(92,1 \%)$ yang melakukan pemanenan berdasarkan musim panen, dan 3 responden $(7,9 \%$ ) yang melakukan pemanenan berdasarkan kebutuhan. Hal ini berarti bahwa pemilik hutan rakyat telah mengetahui waktu pemanenan yang baik sehingga mendapatkan hasil yang baik pula. Hasil hutan bukan kayu menurut FAO (2014) adalah produk biologi asli selain kayu yang diambil dari hutan, lahan perkayuan, dan pohon- 
pohon yang berada di luar hutan. Hasil hutan bukan kayu tersebut biasanya dijual oleh pemilik hutan rakyat dan ada juga yang dikonsumsi karena sebagian hasil hutan bukan kayu merupakan tanaman palawija yang menjadi kebutuhan pokok pemilik hutan rakyat.

\section{d. Pelaksanaan Kegiatan Pemasaran}

Berdasarkan hasil data yang diperoleh, pelaksanaan kegiatan pemasaran yang dilakukan pemilik hutan rakyat/ responden ada 1 responden (2,6\%) termasuk kategori baik, ada 6 responden $(15,8 \%)$ termasuk kategori sedang, dan ada 31 responden $(81,6 \%)$ termasuk kategori buruk. Hal ini berarti sebagian besar pelaksanaan kegiatan pemasaran yang dilakukan pemilik hutan rakyat dapat dikatakan buruk. Hal ini terjadi dikarenakan pemilik hutan rakyat menjual hasil hutan kayunya berupa tegakan berdiri ke pemborong/ pengumpul lantaran tidak memiliki cukup modal untuk biaya penebangan dan pengolahan kayu sehingga penebangan dan pengangkutan kayu dilakukan oleh pembeli, selain itu juga pemilik hutan rakyat menjualnya didasarkan pada kebutuhan mendesak sehingga dalam keadaan ini pemilik hutan rakyat memiliki posisi tawar yang rendah. Dengan cara ini tentulah keuntungan yang diperoleh pemilik hutan rakyat tidak sebesar jika ditebang sendiri ataupun diolah terlebih dahulu.

Kegiatan pemasaran merupakan kegiatan yang dilakukan oleh pemilik hutan rakyat untuk menjual hasil panennya ke pembeli untuk mendapatkan uang sehingga mampu memenuhi kebutuhan hidup keluarganya. Pemasaran menurut Mulyana dan Asmarahman (2010), merupakan kegiatan ekonomi yang bertujuan untuk membawa atau menyampaikan barang dari produsen ke konsumen. Penentuan harga kayu berupa tegakan berdiri dilakukan pemilik hutan rakyat dengan kesepakatan bersama antara pemilik hutan rakyat dan pembeli, sehingga tiap pemilik hutan rakyat menjual kayunya dengan harga yang berbeda-beda. Pohon yang sudah sesuai dengan umur panen ideal dan memiliki diameter yang cukup besar tentu akan dinilai dengan harga yang lebih tinggi dibandingkan dengan pohon yang belum masak tebang.

Sistem pemasaran kayu rakyat melibatkan pelaku pemasaran seperti pemilik hutan rakyat, pedagang pengumpul (tengkulak), industri penggergajian, dan industri barang jadi (Syahadat E, 2012). Adapun saluran pemasaran kayu rakyat yang terdapat di Desa Bandar Dalam adalah sebagai berikut:

a. Model 1

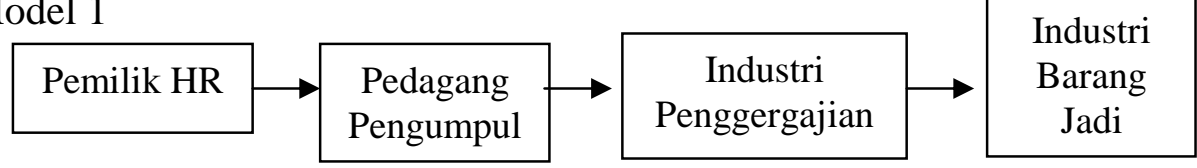

b. Model 2

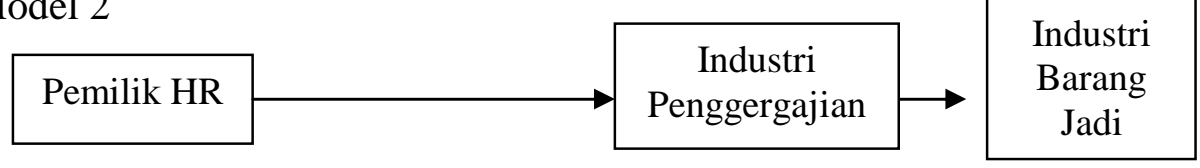

Alur pemasaran yang sering dilakukan oleh pemilik hutan rakyat adalah alur pemasaran model (1). Alur pemasaran model (2) jarang dilakukan karena bila pemilik hutan rakyat menjual langsung ke industri penggergajian, pemilik hutan rakyat harus mengeluarkan biaya eksploitasi yang cukup tinggi.

Pemasaran hasil hutan bukan kayu yang dilakukan pemilik hutan rakyat dari 38 responden ada 3 responden $(7,9 \%)$ yang menjualnya ke pasar, dan ada 35 responden $(92,1 \%)$ yang menjualnya ke pengepul. Hal ini berarti sebagian besar reponden memilih untuk menjual hasil panen non kayunya ke pengepul, ini dikarenakan pemilik hutan rakyat tidak memiliki kendaraan/angkutan untuk mengangkut hasil panennya ke pasar, sedangkan bila dijual di pengepul mereka tidak perlu memikirkan biaya angkutan dan juga resiko-resiko yang disebabkan bila barang tidak laku dijual di pasar. 


\section{Monitoring dan Evaluasi}

Berdasarkan hasil data yang diperoleh, dapat diketahui bahwa semua responden termasuk dalam kategori sedang. Hal ini berarti responden sudah menyadari akan perlunya kegiatan monitoring dan evaluasi untuk mengatasi permasalahan yang dihadapi di hutan rakyat tetapi tingkat pemahaman responden masih perlu ditingkatkan agar manfaatnya bisa diperoleh secara berkelanjutan. Kegiatan monitoring dilakukan dengan memantau lahan yang dikelola oleh pemilik hutan rakyat dan evaluasi dilakukan dengan berdiskusi.

Kegiatan monitoring dan evaluasi merupakan kegiatan yang dilakukan oleh anggota kelompok milik hutan rakyat untuk mengawasi kegiatan yang sudah direncanakan apakah sudah tepat dalam pelaksanaannya dan juga menilai apakah pengelolaan hutan rakyat sudah sesuai dengan harapan pemilik hutan rakyat (Awang, 2008). Seluruh anggota kelompok pernah melakukan kegiatan monitoring dan evaluasi, tetapi hanya kadang-kadang saja dilakukan. Hal ini dikarenakan kegiatan ini tidak dilakukan secara teratur. Frekuensi waktu kegiatan monitoring dan evaluasinya tidak menentu dikarenakan pengurus dan anggota kelompok milik hutan rakyat memiliki kesibukannya masing-masing sehingga sulit menemukan waktu yang tepat agar seluruh anggota dapat hadir.

Sebagian besar responden (20 responden $(52,6 \%)$ ) menganggap kegiatan ini hanya perlu dilakukan sesekali saja karena responden mempunyai banyak kesibukan sehingga tidak bisa untuk selalu melakukan monitoring dan evaluasi, 15 responden $(39,5 \%)$ menganggap kegiatan ini harus selalu dilakukan agar pemilik hutan rakyat dapat saling bertukar pikiran untuk memecahkan masalah yang dihadapi pada lahan yang dikelolanya, dan sisanya 3 responden $(7,9 \%)$ menganggap kegiatan ini tidak harus dilakukan karena mereka merasa mampu untuk mengatasi permasalahannya sendiri.

Materi yang dibahas dalam kegiatan ini adalah mengenai kegiatan yang dilakukan oleh pemilik hutan rakyat dalam menggarap lahannya yang ada di hutan rakyat seperti tanaman apa yang sebaiknya ditanam, bagaimana cara menanam yang baik, bagaimana melakukan pemeliharaan yang baik, serta bagaimana melakukan pemanenan dan pemasaran yang baik pula. Menurut responden kegiatan ini perlu adanya perbaikan terutama mengenai pertemuan karena agar kegiatan monitoring dan evaluasi ini dapat berjalan dengan baik perlu adanya pertemuan yang rutin untuk membahas permasalahan yang terjadi dan bersama-sama mencari solusi.

Berdasarkan hasil wawancara dengan responden, Dinas Kehutanan memang pernah melakukan monitoring secara langsung ke lahan hutan rakyat tetapi hanya kadang-kadang saja atau biasanya kegiatan ini dilakukan ketika ada proyek tertentu. Semua responden mengatakan bahwa kegiatan monitoring dari Dinas Kehutanan perlu sering dilakukan agar hutan rakyat di Desa Bandar Dalam dapat dikelola dengan lebih baik lagi. Selain itu dengan adanya kegiatan monitoring dari Dinas Kehutanan, pemilik hutan rakyat dapat memberitahukan kendala-kendala yang dihadapi pada lahan hutan rakyat yang dikelolanya. Sudah seharusnya Dinas Kehutanan lebih mengintensifkan pengawasan dan pembinaan terhadap kelompok pengelola hutan rakyat di Desa Bandar Dalam karena menurut Dinas Kehutanan (2011), fokus Dinas Kehutanan dalam pengelolaan hutan rakyat adalah pada pembangunan hutan rakyat, pemeliharaan dan pengkayaan dalam rangka peningkatan potensi dan kualitas tegakan hutan rakyat, pembentukan unit manejemen pengelolaan hutan rakyat lestari berbasis masyarakat dan pengembangan sistem agroforestry untuk mendorong diversifikasi usaha hutan rakyat sebagai entry point dalam penanggulangan kemiskinan masyarakat di lahan marjinal dan disekitar hutan. Selain monitoring dari Dinas Kehutanan perlu juga adanya monitoring dari lembaga Non Dinas seperti LSM (Lembaga Swadaya Masyarakat). Menurut Nano (2008), LSM sebagai pendamping dalam membina aktivitas kelompok (masyarakat) bertugas menyertai proses pembentukan dan penyelenggaraan kelompok (masyarakat) sebagai fasilitator (pemandu), komunikator (penghubung), 
dinamisator (penggerak), maupun sebagai motivator (penggali), yang pada hakekat dan tujuannya adalah membantu rakyat kecil yang rentan dan miskin untuk diberdayakan kemudian berkembang atas kekuatan mereka sendiri, atau dengan kata lain membantu proses kemandirian atau keswadayaan masyarakat. Sayangnya belum pernah ada monitoring yang dilakukan oleh lembaga Non Dinas pada hutan rakyat di Desa Bandar Dalam.

\section{Tingkat Pengelolaan Hutan Rakyat}

Secara keseluruhan tingkat pengelolaan hutan rakyat di Desa Bandar Dalam termasuk dalam kategori sedang dengan jumlah skor nilai yang diperoleh dari keseluruhan kegiatan sebesar 3626. Skor nilai ini diperoleh dari penjumlahan seluruh aspek kegiatan yaitu kegiatan perencanaan, organisasi, pelaksanaan, dan monitoring evaluasi. Distribusi hasil pelaksanaan seluruh kegiatan dapat dilihat pada tabel 3.

Tabel 3. Pelaksanaan seluruh kegiatan.

\begin{tabular}{clrrl}
\hline No. & Jenis Kegiatan & Jumlah Skor & Jumlah Rata-rata & Kategori \\
\hline 1 & Perencanaan & 778,95 & 55,64 & Sedang \\
2 & Organisasi & 569,74 & 47,48 & Sedang \\
3 & Penanaman & 668,42 & 66,84 & Baik \\
4 & Pemeliharaan & 450 & 64,29 & Sedang \\
5 & Pemanenan & 543 & 67,93 & Baik \\
6 & Pemasaran & 114,47 & 38,16 & Buruk \\
7 & Evaluasi dan & 501 & 50,13 & Sedang \\
\hline & Monitoring & 3626 & 390,46 & Sedang \\
\hline
\end{tabular}

Sumber: Data Primer (2014)

Berdasarkan tabel 3 diperoleh hasil bahwa tingkat pengelolaan hutan rakyat di Desa Bandar Dalam termasuk dalam kategori sedang, meskipun demikian hutan rakyat tersebut dapat memberikan manfaat bagi masyarakat yang ikut berpartisipasi dalam pengelolaan hutan rakyat seperti peningkatan pendapatan, pemenuhan kebutuhan kayu dan pangan, serta peningkatan produktivitas lahan milik rakyat. Selain itu juga bermanfaat bagi masyarakat sekitar hutan sebagai penyedia oksigen, penyerap karbon dioksida, pencegah erosi, pencegah banjir, penjerap air, dan banyak hal lainnya.

\section{KESIMPULAN}

1. Karakteristik sosial dan ekonomi masyarakat di Desa Bandar Dalam yang mengelola hutan rakyat sebagian besar termasuk dalam usia produktif kerja dan mempunyai pekerjaan sampingan, jumlah tanggungan keluarga hanya sedikit dan luas lahan hutan rakyat yang mereka kelola cukup luas sehingga pendapatan mereka cukup tinggi, meskipun sebagian besar tingkat pendidikannya rendah.

2. Pengelolaan hutan rakyat yang dilakukan pemilik hutan rakyat di Desa Bandar Dalam terdiri dari aspek perencanaan yang termasuk dalam kategori sedang, aspek organisasi termasuk dalam kategori sedang, aspek pelaksanaan penanaman termasuk dalam kategori baik, aspek pelaksanaan pemeliharaan termasuk dalam kategori sedang, aspek pelaksanaan pemanenan termasuk dalam kategori baik, aspek pelaksanaan pemasaran dalam kategori buruk, dan aspek monitoring dan evaluasi termasuk dalam kategori 
sedang. Secara keseluruhan tingkat pengelolaan hutan rakyat di Desa Bandar Dalam termasuk kategori sedang.

\section{SARAN}

Pemerintah dalam hal ini dinas terkait harus lebih mengintensifkan pengawasan dan pembinaan terhadap kelompok pengelola hutan rakyat di Desa Bandar Dalam Kecamatan Sidomulyo Kabupaten Lampung Selatan untuk meningkatkan produktivitas dan kinerja kelompok dalam melaksanakan usahanya.

\section{DAFTAR PUSTAKA}

Alviya, I., N. Sakuntaladewi dan I. Hakim. 2007. Pengembangan Sistem Pengelolaan Hutan Rakyat di Kabupaten Pandeglang. Jurnal Pusat Penelitian Sosial Ekonomi dan Kebijakan Kehutanan. Vol. 7 No. 1, Maret 2007. 45 - 58 p.

Arikunto, S. 2011. Prosedur Penelitian Suatu Pendekatan Praktik. Buku. Rineka Cipta. Jakarta. $370 \mathrm{p}$.

Awang, San Afri, W. T. Widayanti, B. Himmah, A. Astuti, R. M. Septiana, Solehudin dan A. Novenanto. 2008. Panduan Pemberdayaan Lembaga Masyarakat Desa Hutan $(L M D H)$. Buku. Harapan Prima. Jakarta. 158 p.

Badan Kependudukan dan Keluarga Berencana Nasional. 1994. Informasi Pelayanan Kontrasepsi. Buku. Badan Kependudukan dan Keluarga Berencana Nasional Republik Indonesia. Jakarta. 369 p.

Badan Pusat Statistik. 2014. Laporan Bulanan Data Sosial Ekonomi. Buku. Badan Pusat Statistik Republik Indonesia. Jakarta. 136 p.

Basir, Bartos. 1999. Manajemen Sumber Daya Manusia Suatu Pendekatan Makro. Buku. Bumi Aksara. Jakarta. 246 p.

Departemen Kehutanan. 1999. Undang-undang No.41 tahun 1999 tentang Kehutanan. Salinan Kepala Biro Hukum dan Organisasi. Dephutbun. Jakarta. 62 p.

Dinas Kehutanan Kabupaten Malang. 2011. Sasaran Pelayanan. Diakses pada tanggal 6 Januari 2015. Pukul 15.00 WIB. Sumber: http://kehutanan.malangkab.go.id /index.php?kode $=41$

FAO. 2014. Non-Wood Forest Product (NWFP). Diakses pada tanggal 6 Januari 2015. Pukul 17.00 WIB. Sumber: http://www.fao.org/forestry/nwfp/6388/en/

Fauziyah, E. 2009. Tingkat Partisipasi Masyarakat Pontren Dalam Program Pengembangan Hutan Rakyat. Jurnal Prosiding Seminar Hasil-Hasil Penelitian Balai Kehutanan Ciamis. 342 - 349 p.

Hardiatmi, JM. Sri. 2010. Investasi Tanaman Kayu Sengon Dalam Wanatani Cukup Menjanjikan. Jurnal Inovasi Pertanian. Vol. 9 No. 2, September 2010. 17 - 21 p.

Mahbub, M, A, S. 2007. Penyuluhan Kehutanan Partisipatif. Jurnal Hutan dan Masyarakat. Vol. 2 No. 3.313 - 318 p.

Mulyana, D dan Asmarahman, C. 2010. 7 Jenis Kayu Penghasil Rupiah. Buku. PT. AgroMedia Pustaka. Jakarta. 134 p.

Nano. 2008. Peran Lembaga Swadaya Masyarakat Dian Desa Yogyakarta Dalam Pemberdayaan Masyarakat Pesisir Utara Tegal Jawa Tengah. Skripsi. Universitas Islam Negeri Sunan Kalijaga. Yogyakarta. 62 p. 
Pramono, A.A., Fauzi, M.A., Widyani, N., Heriansyah, I. dan Roshetko, J.M. 2010. Pengelolaan Hutan Jati Rakyat: Panduan Lapangan Untuk Petani. Buku. CIFOR, Bogor, Indonesia. $75 \mathrm{p}$.

Saihani, A. 2011. Analisis Faktor Sosial Ekonomi Terhadap Pendapatan Petani Padi Ciherang di Desa Sungai Durait Tengah Kecamatan Babirik Kabupaten Hulu Sungai Utara. Jurnal ZIRAA'AH. Vol 31 No. 3, Oktober 2011. 219 - 225 p.

Sajogyo. 1977. Garis Kemiskinan dan Kebutuhan Minimum Pangan. Buku. Pusat Studi Pembangunan Pertanian dan Pedesaan LPPMIPB. Bogor. 33 - 42 p.

Setiawan, A, I. 1996. Penghijauan Lahan Kritis. Buku. PT. Penebar Swadaya. Anggota IKAPI. Jakarta. $81 \mathrm{p}$.

Simon, Hasanu. 2004. Membangun Desa Hutan Kasus Dusun Sambiroto. Buku. Gadjah Mada University Press. Yogyakarta. 156 p.

Sudiana, E., Hanani, N., Yanuwiadi, B., Soemarno. 2009. Pengelolaan Hutan Rakyat Berkelanjutan di Kabupaten Ciamis. Jurnal Agritek. Vol. 17 No. 3, Mei 2009. 543 $555 \mathrm{p}$.

Sugiyono. 2008. Metode Penelitian Kuantitatif Kualitatif dan R\&D. Buku. Alfabeta. Bandung. 215 p.

Suryaningsih, W. H., H. Purnaweni, dan M. Izzati. 2012. Persepsi Masyarakat Dalam Pelestarian Hutan Rakyat di Desa Karangrejo Kecamatan Loano Kabupaten Purworejo. Jurnal Prosiding Seminar Nasional Pengelolaan Sumberdaya Alam dan Lingkungan tanggal 11 September 2012. Semarang. 93 - 97 p.

Syahadat, E. 2012. Penatausahaan Pemasaran Kayu Rakyat. Diakses pada tanggal 6 Januari 2015. Pukul 11.30 WIB. Sumber: www.fordamof.org/files/penatausahaan-kayuepi.pdf

Widiyanti, Septi. 2009. Studi Kelembagaan Kelompok Tani Hutan Rakyat di Wilayah Cianjur Selatan. Skripsi. Institut Pertanian Bogor. Bogor. 63 p.

Yitnosumarto. 2006. Metode Penelitian Kuantitatif dan Kualitatif. Buku. Graha Ilmu. Yogyakarta. $316 \mathrm{p}$. 
Vol. 3 No. 2, Mei 2015 (99-112)

Halaman ini sengaja dikosongkan 